\title{
PERSEMBAHYANGAN PURNAMA DAN TILEM SEBAGAI MOMENT STRATEGIS UNTUK PENINGKATAN SRADDHA BHAKTI SERTA PEMBINAAN UMAT YOGYAKARTA
}

\author{
I Nyoman Santiawan \\ Dosen Sekolah Tinggi Hindu Dharma \\ Klaten Jawa Tengah
}

\begin{abstract}
Abstrak
Persembahyangan Purnama dan Tilem di Pura Jagadnatha Banguntopo Yogyakarta yang secara rutin dilaksanakan setiap lima belas hari sekali. Dalam implementasi persembahyangan Purnama dan Tilem yang termasuk bagian dari upacara Dewa Yadnya yang dapat dijadikan tempat untuk pembinaan umat. Secara realita yang ada di sekitar khususnya di Banguntapan, pelaksanaan persembahyangan Purnama dan Tilem dilihat tidak diragukan lagi mengenai hal ritual atau upacaranya, tetapi persembahyangan rutin tersebut dapat dimanfaatkan sebagai ajang pembinaan umat yang tepat karena pada saat tersebut umat benar-benar datang untuk mencari ketenangan dan tempat berkumpul untuk mendapatkan pengetahuan. Sebagian umat dalam melaksanakan ritual atau upacara persembahyangan Purnama dan Tilem belum memahami secara mendalam bagaimana makna yang terkadung di dalamnya, makna apa saja yang didapat ketika mengikuti persembahyangan Purnama dan Tilem. Persembahyangan Purnama dan Tilem penting dilaksanakan, sehingga perlu adanya pembinaan setiap saat pesembahyangan. Di Pura Jagadnatha Banguntopo telah menerapkan rangkaian acara persembahyangan Purnama dan Tilem yang tersusun begitu jelas dan terarah. Yang mana di dalam proses persembahyangan memberikan makna tersendiri, mulai dari persiapan, susunan acara yang memberikan banyak pengetahuan dalam peningkatan sraddha dan bhakti sumat. Sehingga persembahyangan Purnama dan Tilem yang diterapkan di Pura Jagadnatha menjadi sebagai moment peningkatan sraddha dan bhakti dan pembinaan umat yang strategis.
\end{abstract}

Kata Kunci : Persembahyangan, Purnama, Pura Jagadnatha dan Pembinaan. 


\section{A. PENDAHULUAN}

Hindu merupakan agama yang tertua di dunia, ajaran-ajaranya bersumber pada kitab suci Veda yang merupakan wahyu Tuhan Yang Maha Esa. Bila seseorang secara mantap mengikuti semua ajaran agama yang bersumber pada sabda suci Tuhan Yang Maha Esa itu, maka akan diperoleh ketentraman dan kebahagiaan hidup yang sejati yang disebut "Moksatam jagadhita ya ca iti dharma"(Titib, 2003 :2). Agama Hindu dikatakan luwes atau sering disebut dengan agama fleksibel. Ini dikarenakan agama Hindu khususnya di Bali menyesuikan dengan sistem desa, kala dan patra. Dalam agama Hindu banyak terdapat ajaran-ajaran yang tentunya tidak menyimpang dari kitab suci Weda. Dalam ajaran Weda yang menjadi dasar pelaksanaan upakara merupakan hal yang sangat penting dalam membentuk karakter keyakinan dalam kehidupan beragama. Dari karakter itu, manusia dapat menjalani hidupnya dengan fokus. Implementasi dalam setiap ajaran agama dalam kehidupan sehari-hari mampu mewujudkan peningkatan sradha dan bhakti terhadap Agama tersebut, salah satunya adalah melaksanakan persembahyangan baik sembahyang hari-hari biasa naupun peresmbahyang Purnama dan Tilem.

Persembahyangan Purnama dan Tilem merupakan hari peenrsebahyang yang rutin ada dalam setiap bulannya dan merupakan praktek wajib penting yang harus dilaksanakan oleh umat Hindu dengan tujuan selain meningkatkan Sraddha dan Bhakti seorang tetapi juga dapat lebih memahami ajaran Agama memalui proses pelaksanaan persembahyangan Purnama dan Tilem. Sehingga dengan meningkatnya sraddha dan bhakti seseorang segala tantangan atau hambatan hidup dan gejolak-gejolak kehidupan bisa teratasi dengan baik. Sehingga selain menjadi moment meningkatkan sraddha dan bhakti umat, dalam proses persembahyangan purnama dan tilem hendaknya pula dijadikan moment sebagai metode pembinaan kepada umat.

Persembahyangan Purnama dan Tilem di Pura Jagadnatha Banguntopo memberikan kesan yang berbeda dengan persembahyangan Purnama dan Tilem di pura lainya, karena tidak hanya rutin dan ramai umat yang bersembahyang di Pura Jagadnatha baik itu dari umat setempat, perantau dan mahasiswa-i, tetapi juga rangkaian proses untuk melaksanakan persembahyangan Purnama dan Tilem memberikan pemahaman yang mendalam melalui proses-proses yang dilakukan, semisal dari mulai mempersiapkan sarana, susunan acaranya dan tata cara pelaksanaan persembahyangan. Dari semua rangkaian tersebutlah dapat dipakai sebagai metode pembinaan kepada umat.

Metode pembinaan umat yang saat ini dilakukan pada peretemuan-pertemuan keumatan baik yang berskala besar maupun skala kecil, mulai dari kumpulan arisaan kumpulan banjar, asrham, pasraman sampai kegiatan upacara kegamaan yang besar. Atas dasar tersebutlah, dapat dinyatakan bahwa persembahyangan Purnama dan Tilem dapat digunakan sebagai metode tambahan untuk pembinaan umat yang strategis dan praktis, dengan demikian fungsi dari persembahyangan Purnama dan Tilem tidak lagi hanya sebagi moment melakukan persembahyangan saja. Rutinya pembinaan yang dilakukan dapat memberikan pemahaman yang kuat terhadap ajaran Agama dan dapat membangun kerukunan hidup berdampingan walaupun bebreda Ras, Agama, Suku dan antar golongann. Pura Jagadnatha terletak di desa Plumbon Banguntapan Bantul Yogyakarta, setiap harinya banyak umat yang datang untuk bersembahyang, terutama pada sore menjelang malam. Kebanyakan yang datang untuk bersembahyang ke Pura Jagadnatha adalah mahasiswa yang mana Yogyakarta merupakan kota pendidikan, jadi banyak mahasiswa Hindu yang berasal dari Bali maupun luar Bali yang datang ke kota Yogyakarata untuk menuntut ilmu. Selalin hari-hari biasa yang paling memberi makna tersendiri adalah pada saat datangnya hari suci Purnama dan Tilem, satu hari sebelum persembahyangan, Purnama dan Tilem pura jagadnatha sudah ramai, ada umat yang membeli canang (sarana persembahyangan) dan umat setempat sudah mulai mempersiapkan 
sarana dan pra sarana persembahyangan Purnama dan Tilem. Dari awal proses, mulai dari pembuatan banten, persiapan dan susunan acara yang dilalui menjadikan ketertarikan tersendiri untuk Persembahyangan Purnama dan Tilem di Pura Jagadnatha ini dijadikan sebagai metode pembinaan umat yang strategis dan contoh untuk diterapkan di seluruh dunia. Sehingga kesempatan untuk pembinaan umat dapat dilakukan secara rutin dan terstruktur, dan juga memberikan pemahaman kepada umat untuk mengikuti setiap persembahyangan dengan baik dan tertib.

Jenis penulisan yang digunakan dalam penulisan ini adalah penelitian kualitatif deskriptif, mengingat permasalahan yang ingin diangkat merupakan masalah sosial keagamaan. Tempat penelitian di Pura Jagadnatha Banguntopo Bantul Yogyakarta, dengan cara observasi, pengamatan, dokumentasi dan wawancara, yang merupakan sumber data yang utama, sedangkan cara analisis datanya yaitu dengan mengamati, memahami, dan menafsirkan setiap fakta atau data yang telah dikumpulkan serta hubungan di antara fakta-fakta atau variable merupakan terkait dalam hipotesis (Sugiyono, 2007 : 244). Data penelitian yang peneliti peroleh melalui observasi dan wawancara dengan informan selama penelitian di lapangan selanjutnya di paparkan, kemudian dicari pokok-pokok penting yang terkandung di dalamnya sehingga dapat di ketahui dengan jelas maknanya. Data yang peneliti peroleh selanjutnya diseleksi dan di kode untuk memperoleh konsep yang lebih sederhana sehingga relatif lebih mudah dipahami.

\section{B. PEMBAHASAN}

\section{Gamabaran Umum Pura Jagadnatha Banguntopo}

Pura Jagatnatha Yogyakarta diempon oleh warga asli Banguntapan sebanyak 80 kepala keluarga (KK). Sementara pengempon asal Bali dari tempekan Eka Cita Dharma yang berjumlah $33 \mathrm{KK}$, yang berdomisili di Bantul, Sleman, Kodya Yogyakarta, Wanasari (Gunung Kidul). Lokasi pura ini dulu juga pernah digunakan sebagai tempat bertapa Hamengku Buwono II sampai mendapatkan gelar Ki Banguntapa. Sejarah berdirinya pura ini mulai pada tahun 1967. Saat itu Kelurahan Banguntapan banyak disinggahi masyarakat pemeluk agama Hindu, hingga terbentuk Majelis Umat Hindu Dharma di wilayah Banguntapan. Awalnya hanya satu Pelinggih dan area pura sangat kecil. Pada tahun 1975 masyarakat pemeluk agama Hindu mulai membangun Pura Jagatnatha, dengan membangun gedung persembahyangan model Jawa dan Padmasana. Dari tahun 1976 sampai tahun 1982 dilanjutkan pembangunan gedung kori, pemagaran kanan dan kiri, pembangunan candi bentar, dan tembok penyengker. Tahun 2006 sebagian bangunan pura hancur akibat gempa bumi. Setahun kemudian dilakukan perbaikan atas bantuan dana dari Pemerintah Provinsi Bali, Pemkab Bantul, dan pemedek. Adapun Pujawali/Piodalan di pura ini bertepatan Hari Raya Galungan yakni pada setiap Budha Kliwon Dunggulan. Ribuan umat sembahyang setiap Pujawali. Ratusan Umat juga sembahyang saat Purnama, Tilem, dan khususnya saat Kliwon.

Pura Jagadnatha Banguntopo berdiri di lahan seluas $\pm 3800 \mathrm{~m} 2$, secara susunan letak, memiliki 3 mandala, lahan parkir dan sekolah taman kanak-kanak. Pada Mandala Utama, terdapat Pelinggih utama yaitu Padmasana, Pengayengan, Penunggun Karang/Pelinggih Hyang Banguntopo, Gedong Penyimpenan, Bale Sembahyang kiri dan kanan, Pendopo Tengah dan Bale Pawedan. Pada Mandala Madya terdapat bangunan Bale Pewaregan atau Dapur, Bale Mepligbagan/Diskusi dan Perpustakaan, Bangunan Pensucian dan Bale Kulkul. Sedangkan Mandala Tiga/Nista terdapat gedung Sansana, Ruang Rapat, Sekretariat dan Toilet. Gedung Santi Sasana digunakan untuk acara-acara besar seperti Dharma Santi, Pernikahan, Bazzar, Pentas Seni dan Seminar, Pasraman. 
Di Pura Jagadnatha Banguntopo banten adalah sarana yang pasti dipakai dalam persembahyangan Purnama dan Tilem, banten tersebut berupa 4 buah Pejati, 16 buah Ajuman, 7 Segehan, Prayascita, satu paket pisang dan salak dan wedang tape dilengkapi dengan kentang rebus. 4 pejati masing-masing dihaturkan di Padmasana, Pelinggih Pengayengan, Pelinggih Hyang Banguntopo dan Bale Pawedan untuk adepan Wasi. 16 Ajuman masing-masing dihaturkan di Beji, Gedong Penyimpenan, Pendopo Tengah, Kori Agung kiri dan kanan, dapur, Bale Kulkuk, Ringin, Candi bentar kiri dan kanan, parkir selatan dan utara, Gedung Santi Sasana, dan Candi bentar pintu keluar sebelah selatan dan Bale Mepligbagan. Segehan di masing-masing bawah pejati, halaman tengah, bawah ringin, pintu keluar kiri kanan dan tengah. Untuk benten buah pisang dan salak matamas dan susu 1 gelas dihaturkan di Padmasana pada saat Tilem dan Wedang Tape kentang rebus di Pelinggih Hyang Banguntopo.

\section{Proses Persembahyangan Purnama dan Tilem di Pura Jagadnatha Banguntopo}

Persiapan pelaksanaan persembahyangan Purnama dan Tilem dilakukan oleh paguyuban ibu-ibu dan muda-mudi dan tentu didukung dana oloeh penyungsung. Pada persiapan persembhayangan Purnama, banten dan sarana-sarana dipersiapkan oleh paguyuban ibu-ibu Banguntapan, paguyuban ibu-ibu ada 3 kelompok, yaitu kelompok Plumbon, Sanggrahan dan Sorowajan. Setiap Persiapan pelaksanaan persembahyangan, masing-masing kelompok Paguyuban dibagi tugas, misalnya purnama bulan Agustus paguyuban ibu-ibu Plumbon, kemudian Purnama bulan September dikerjakan oleh paguyuban ibu-ibu sanggrahan dan Purnama bulan Oktober dikerjakan oleh Paguyuban ibu-ibu Sorowajan, begitu pula Purnama berikutnya. Sedangkan pada saat persiappan pelaksanaan persembahyangan Tilem disiapkan oleh muda-mudi. Muda-mudi mempersiapakan banten upakara, sarana persembahyangan dan menjaga parkir kendaraan umat. Awalnya muda-mudi mempersiapkan pada saat Purnama, karena berkembangnya waktu dan kesibukan muda-mudi, sehingga memilih Tilem.

Pelaksanaan persembahyangan Purnama dan Tilem dilaksanaka pada malam hari $\mathrm{H}$ pukul 19.00 pada gelombang pertama dan dilanjutkan gelombang kedua pada pukul 20.45 dan gelombang selanjutnya pada pukul 21.30. Banyaaknya umat yang tangkil mengharuskan persembahyanang dibuat pergelombang. Dengan diadakannya sitem gelombang, maka umat yang tangkal dapat menyesuaikan dengan kesibukan pribadinya. Namun sebelumnya petugas pelaksanan persembahyangan sudah datang dan mempersiapkan segalanya 30 menit sebelum persembahyangan dimulai. Dari data yang didapat, dapat disimpulkan bahwa pesembahyanga dimulai di hari $\mathrm{H}$ dan memakai sistem gelombang. Menurut data yang diterima, ini sudah berlangsung tepatnya tahun 2001.

susunan acara pesembahyangan pada saat ini sangat tertata dan terarah. Susunan Acara diupayakan mengalami perbaikan-perbaikan. Sampai yang sekarang adalah susunan acara yang terbaik. Adapun susunan acara yang dula dan yang sekarang adalah sebagai berikut: pembukaan, maturan bebantenan diiringi dengan kekidungan, pembacaan sloka, dharma wacana, persembahyangan Puja tri sandya dilanjut kremaning sembah kemudian nunas tirta, pengumpula dana punia dan pengumuman-pengumuman dan penutup.

\section{Praktek Keagamaan yang terkandung dalam proses Persembahyangan Purnama dan Tilem di Pura Jagadnatha Banguntapan.}

Praktek keagamaan atau juga disebut dengan Dharma Sadhana merupakan realisasi ajaran agama dalam kehidupan sehari-hari. Dalam proses pelaksanaan persembahyangn Purnama dan Tilem di Pura Jagadnatha ada beberapa Dharma Sadhana yang tekandung diantaranya sebagai berikut:

\section{a) Mejejahitan atau Pembuatan Banten}


Majejahitan dan metanding menjadi aktivitas di balik semua ritual atau upacara-upacara keagamaan. Dan ini menjadi bagian teramat penting dari sebuah prosesi ritual. Semua perhatian dan konsentrasi seorang yang sedang menjahit canang atau banten difokuskan untuk mencipta keindahan. Terfokus pada kelembutan, ketenangan nafas, kesabaran. Keheningan menjadi sesuatu yang tidak bisa ditawar untuk menghasilkan karya keindahan. Karena karya keindahan ini untuk persembahan kepada Hyang Maha Tunggal, bhakti (cinta pada Tuhan) menghidupi tarikan nafas mereka yang sedang majajahitan. Keheningan, kesabaran, bhakti, semua diarahkan untuk keindahan. Matanding dan majejahitan, yang juga bagian integeral dari muspa (dalam arti luas), adalah pengayaan diri terhadap keindahan. Matanding dan majejahitan adalah semacam universitas terbuka dalam rakyat Bali yang memberi kuliah apresiasi estetik. Dalam matanding dan majejahitan perempuan-perempuan Hindu belajar dan mewariskan apresiasi mereka terhadap estetika, terhadap unsur-unsur alam yang menjadi bagian tak terpisah dari sebuah banten atau canang. Sehingga, kelanjutannya, ketika banten dan canang digelar di tempat persembahyangan, kegiatan itu semacam festival merangkai bunga. Janur dan bunga menghiasi seluruh pura. Tanpa terasa, setiap hari persembahyangan, Hindu sesungguhnya mengadakan sebuah festival keindahan.

Praktek keagamaan mejejaitan di pura Jagadnatha sendiri berdasarkan pemantauan peneliti setiap persiapan persembahyangan mejejaitan adalah proses pertama yang dilewati. Dengan mejejaitan, umat dapat merasakan bhakti yang telah dilaksanakan, karena dari mejejaitan mendapat ketenangan jiwa dan kepuasan hati dalam karya yang dipersembahkan. Penting bagi semua umat Hindu untuk memahami bagaimana sebenarnya makna filosipi yang terkandung dalam mejejaitan, agar prpses mejejaitan tersebut bisa berjalan dengan baik.

\section{b) Kekidungan}

Kidung merupakan nyanyian keagamaan yang dilantunkan pada saat kegiatan Yadnya. Dalam kegiatan upacara agama Hindu yang biasanya dirancang serta dilaksanakan dengan semarak dan meriah. Juru kidung meresitasikannya sebagai kidung pembukaan untuk menandai dimulainya suatu prosesi upacara agama Hindu. Seni tembang kidung merupakan seni tembang yang sangat penting dalam upacara-upacara agama Hindu. Seni tembang yang tergolong sekar madya pada umumnya mempergunakan bahasa Jawa Tengahan, yaitu seperti bahasa yang dipergunakan di dalam lontar/ cerita Panji atau Malat, dan tidak terikat oleh Guru Lagu maupun Padalingsa. Kidung diduga datang dari Jawa abad XVI sampai XIX akan tetapi kemudian kebanyakan ditulis di Bali. Dalam upacara-upacara agama Hindu kidung dinyanyikan untuk mengiringi upacara yadnya. Kidung memiliki tugas masing-masing dalam mengiringi upacara. Misalnya saja dalam upacara Dewa Yadnya kidung yang dinyanyikan adalah kidung Kawitan Wargasari, Wargasari Mredu Komala dan kidung yang lain yang cocok dinyanyikan dalam upacara Dewa Yadnya. Upacara-upacara yang lain juga memiliki kidung-kidung yang mengiringi upacara tersebut. Dalam persembahyangan Purnama dan Tilem di Pura Jagadnatha, kidung yang digunakan adalah kidung Jawa yang diawali dengan Puspa Hati, kemudian Mantram Gurur dilanjutkan dengan tembang Hamurwaning. Kidung yang seperti itu biasanya dilantunkan oleh bapak-bapak dan ibu-ibu Paguyuban Banguntapan. Sedangkan pada saat mahasiswa yang mendapat tugas, mahasiswa memakai kidung yang pada umumnya, yaitu kidung wargasari.

\section{c) Pembacaan Wedawakya}

Pembacaaan Weda Wakya merupakan praktek yang sangat penting, karena dengan dilantunkannya mantra-mantra suci di mana-mana akan memberikan pencerahan dan energi positif. Menurut (Nyoman Kadjeng, dkk 2003), keutamaan jika seeorang mendengarkan sastra suci itu, sekali-kali ia idak akan berkemauan untuk mendengarkan cerita-cerita lain, termasuk nyanyian-nyanyian rebab,seruling dan yang lain-lain semacam itu. Sebagai 
misalnya orang yang sudah pernah mendengarkan keindahaan suara burung kutilang, yang telah meresap ke dalam hatinya, keindahaan suara burung itu dapat membangkitkan kesenangan hatinya. Seperti kutipan Bhagawad Gita XVIII.70.

"Adyesyate ca ya imam dharmyam samvadam avayoh, jnyanayadnyena tena'ham istah iti me matih"

Artinya: Dia yang selalu membaca percakapan suci ini, AKU angga dia Penyembah-KU dalam wujud Yadnya (Yadnya dengan ilmu pengetahuan)

Sloka suci Bhagawad Gita, Kekidungan yaitu sejenis wirama/kekawin/syair bahasa Sansekerta dengan suku kata yang berjumlah delapan. Kalau tepat cara melantunkan syairnya dapat menggetarkan partikel-partikel alam yang ada di sekitar kita hingga mampu menembus alam kedewataan. Dengan alunan kidung suci dapat pula menyejukan alam sekitar yang mendengar alunan kidung suci ini. Dalam Bhagawad Gita XVIII.71.

api yo narah, so'pi muktah subham lokam prapnuyat punya karmanam." "Srinuyad

Artinya: Waluapun hanya mendengar alunan suci ini ia juga akan terbebaskan, mencapai dunia kebahagiaan dan akan mencapai kebajikan dalam berprilaku/karma.

Atas dasar sabda suci diatas, Pembacaan Weda Wakya pada saat persembahyangan Purnama dan Tilem di Pura Jagadnatha rutin dilakukan. Selalin penting juga memberikan warna tersendiri dalam rangkaian acara persembahyangan di Pura Jagadnatha, pasalnya pembaca Weda Wakya berasal dari berbagai jennjang umur, golongan dan daerah. Pembacaan Weda Wakya juga memberikan kesan yang sangat mendalam bagi umat, kerena mendengar sastra suci yang disampaikan dengan irama yang berbeda-beda merupakan model yang unik, sehingga model pembacaan Weda Wakya yang diketahui secara umum ternyata tidak hanya seperti itu saja cara membacanya, disesuaikan dengan desa, kala dan patra. Pembacaan Wedawakya di Pura Jagadnatha dilakukan oleh umat yang bertugas pada malam itu, baik itu mahasiswa, ibu-ibu, bapak-bapak maupun pemuda dan pemudi. Kebiasaan itu telah dilaksanakan sudah lama dan mendapat kesepakatan bersama. Karena sebulum bertugas, ada pelatihan-pelatihan utuk pembacaan Wedawakya.

\section{d) Dharma Wacana}

Dharma wacana mengandung arti mewacanakan Dharma ditengah-tengah masyarakat. Kata ini berasal dari bahasa sansekerta wacana yang berkaitan dengan kebenaran atau spiritual. Didalam bahasa latin di kenal dengan istilah oratori. Kegiatan mewacakan Dharma ini di masa lalu di sebut Upanisad. Terminilogi Upanisad atau Upanisada mengandung arti dan sifat yang Rahasyapadesa dan merupakan bagian dari kitab sruti. Pada masa yang lalu ajaran upanisad sering di hubungkan dengan "pawesik" yakni rahasia yang di berikan oleh seorang guru kerohanian kepada siswa atau muridnya dalam jumlah yang sangat terbatas. Dengan istilah Dharma Wacana di maksudkan sebagai methode penerangan Agama Hindu yang di berikan secara umum kepada umat Hindu sesuai dengan sifat, tema, bentuk, jenis kegiatan keagamaan yang di laksanakan menurut desa (tempat), kala (waktu) dan patra (keadaan), (Badan Penyiar Agama Hindu Sulawesi Tenggara, 2015).

Dharma Wacana merupakan persembahan berupa ilmu pengetahuan disebut Jnana Yadnya. Yadnya ini merupakan persembahan yang sangat mulia dan tidak membutuhkan biaya yanga banyak. Dalam kitab Bhagawad Gita IV.33 dinyatakan sebagai berikut:

"Sreyan dravyamayad yadnyaj, jnyanayadnyaah paramtapa. Sarwam karmaa'khilam partha, jnyame parsamaapyate."

Artinya: Lebih utama persembahan jnyana yandnya daripada persembahan materi dalam wujud apapun, sebab segala pekerjaan apapun hendaknya harus berdasarkan ilmu pengetahuan suci (jnyana).

Persembahyangan Purnama dan Tilem di Pura Jagadnatha Banguntopo tidak lepas dari dharma wacana, karena pada saat persembahyangan itu umat banyak yang tangkil dan 
momen yang tepat, sehingga pura berfungsi sebagaimana mestinya yatu sembagai tempat bersosial, berbhakti dan pembinaan umat. Dharma Wacana yang terlaksana di Pura Jagadnatha Banguntopo, sangat majemuk, yang mengisi ada dari kalangan Dosen, Pengusaha, Guru, Mahasiswa, anak-anak maupunmasyarakat biasa. Itu dikarenakan konsep yang dianut oleh pengempon pura dalam menentukan petugas dharma wacana sangatlah simpel dan terbuka untuk siapa saja yang mau ngayah, asalkan isi Dhama Wacananya berkaitan dengan ajaran keagamaan, motivasi spiritual maupun pengetahuan umum yang tentunya bisa dijadikan acuan untuk menjalankan kehidupan yang lebih baik.

\section{e) Dana Punia}

Dana punia menurut Hindu merupakan salah satu ajaran yang harus dihayati dan diamalkan. Pengertian dana punia adalah pemberian yang baik dan suci dengan tulus ikhlas sebagai salah satu bentuk pengamalan ajaran dharma. Sesuai dengan asal kata dana punia, dana berarti pemberian dan punia berarti selamat, baik, bahagia, indah dan suci. Dana punia merupakan suatu sarana untuk meningkatkan sradha dan bhakti kita kepada Tuhan YME, selain itu dengan berdana punia akan membangun sikap kepedulian kita terhadap sesama, (KataHindu, 2012). Sudarma 2013, Weda yang merupakan wahyu Tuhan yang dengan demikian tanpa keraguan sedikit pun kita dapat simpulkan bahwa berdana punia adalah wajib hukumnya bagi umat Hindu. Kita semua berkewajiban untuk melakukan dana punia sesuai dengan swadharma kita masing-masing sebagai umat Hindu. Dana punia dapat disalurkan kepada orang yang membutuhkan atau yang berhak menerima seperti: guru rohani/nabe, sulinggih, orang miskin, orang cacat, siswa putus sekolah, orang yang terkena musibah, tempat suci, lembaga sosial, pasraman/pendidikan dan lain sebagainya. Dalam kotab suci ada beberapa sloka yang menyatakan:

"na mata na pita kincit kasyacit pratipadyate, danapathyodano jantuh svakarmaphalam acnute" (Sarasamuccaya 16)

Artinya: Barang siapa yang memberikan dana punia maka ia sendirilah yang akan menikmati buah (pahala) dan kebajikannya itu.

dese kale ca patre ca, tad danam sattvikam smrtam"(Bhagawad Gita XVII.20 )

Artinya: Sedekah yang diberikan tanpa mengharap kembali, dengan keyakinan sebagaikewajiban untuk memberikan pada tempat, waktu dan penerima yang berhak, disebut sattvika.

Beberapa uraian sloka diatas dapat menjadi pedoman dan berdana punia merupakan kewajiban kita sebagai umat hindu. Dalam persembahyangan Purnama dan Tilem di Pura Jagadntha Banguntopo, umat yang berdana punia sangat antusias, itu terlihat setiap persembahyangan Purnama dan Tilem, dana punia yang terkumpul Rp. 2.000.000,- sampai Rp. 5.000.000,-, berbeda lagi dengan kotak punia yang dibuka setiap tilem yang paling sedikit isi kotak punianya sebesar Rp.10.000.000,-. Ini merupakan kesadaran yang umat yang sangat mulia dan sangat paham tentang makna berdana punia, walaupun kebanyakan di Pura kebanyakan yang nangkil mahasiswa.

Dalam pembahasan diatas, proses persembahyangan Purnama dan Tilem di Pura Jagadnatha Banguntopo sangatlah baik dan tertata, bahwa dalam persembahyangan tidak hanya mementingkan bagaimana persembahyangan itu bisa dilaksanakan, tetapi setiap tahap demi tahap proses menuju sampai selesai dalam rangkaian persembahyangan bisa memberikan makna yang lebih mendalam bagi semua umat. Purnama dan Tilem merupakan hari suci keagamaan dan pada saat Purnama dan Tilem permohonan anugerah yang berlimpah dan keselamatan merupakan kuci utama pelaksanaan persembahyangan. 


\section{Sembahyangan Purnama dan Tilem Di Pura Jagadnatha Banguntopo sebagai media Pembinaan Strategis}

Persembahyangan Purnama dan Tilem di Pura Jagadnatha Banguntopo merupakan kegiatan umat Hindu yang secara rutin dan tertata dilaksanakan, yang merupakan suatu tugas pengempon yang mengerjakannya terutama umat yang paguyuban Banguntapan. Persembahyangan yang melalui proses dan tertata sedemikian rapi, yang diikuti secara hening dan harmonis menjadikan menjadikan persembahyangan Purnama dan Tilem sebagai hari yang ditungu banyak masyarakat terutama bagi mahasiswa. Proses pelaksanaan dan susunan acara yang pada persembahyangan Purnama dan Tilem yang memberikan pemaknaan penting bagi umat yang menpersiapkan dan yang datang dalam persembahyangan Purnama dan Tilem. Dari data yang telah diolah, banyak sekali pengetahuan-pengatahuan untuk peningkatan Sraddha dan Bhakti yang didapat dalam proses persembhayangan Purnama dan Tilem. Mulai dari persiapan pembuatan sarana perembahyangan (banten, Canang, dan sarana persembahyangan) sampai susunan acara dalam persembahyangan seperti Pembacaan Sloka, Dharma Wacana, Kekidungan dan Dana Punia yang wajib disajikan, menjadikan suatu kontribusi khusus yang didapat oleh umat yang ikut persembahyangan Purnama dan Tilem. Umat yang mempersiapkan dengan senang hati dan hati yang tulus menjalankan tugas merupakan suatu peningkatan Sraddha dan Bhakti bagi umat. Pengetahuan dan pemaknaan yang mendalam didapat oleh umat yang datang padi saat persembahyangan Purnama dan Tilem yang dengan tertib mengikuti acara demi acara yang disajikan. Berdasarkan itu, Persembahyangan Purnama dan Tilem di Pura Jagadnatha Banguntopo telah menjadi Moment yang Strategis dalam peningkatan Sraddha dan Bhakti serta pembinaan umat.

\section{SIMPULAN}

Dari hasil pengamatan, wawancara serta pembahasan di atas kesimpulan yang didapat setelah melakukan penelitian adalah sebagai berikut: Dalam persembhayanga Purnama dan Tilem di Pura Jagadantha Banguntopo dapat disimpulkan bahwa setiap persembahyangan memberikan pemaknaan dan pengetahuan yang mendalam bagi umat sehingga umat yang datang Sraddha dan Bhakti meningkat. Mulai dari proses persembahyangan Purnama dan Tilem sangat tertata, mulai dari mempersiapkan banten, mempersiapkan tempat sembahyang dan juga susunan acara yang sangat terarah.Praktik keagamaan di dalam proses persembahyangan Purnama dan Tilem sangat baik dan tidak hanya seorang datang cuma sembahyang saja, tetapi juga mendapat pengetahuan-pengetahuan keagamaan. Karena praktek keagamaan yang terlihat banyak, seperti mejejaitan, kidung, pembacaan weda wakya/sloka, dharma wacana dan dana punia. Persembahyangan Purnama dan Tilem telah tebukti memiliki konsep pelaksanaan persembahyangan Purnama dan Tilem di Pura Jagdnatha hendaknya menjadi contoh untuk semua pura. Sehingga umat Hindu tidak hanya dapat pembinaan di tempat-tempat yang khusus dan waktu-waktu tertentu.

Persembahyangan Purnama dan Tilem menjadi kewajiban yang dasar dari oleh umat untuk mengungkapan rasa syukur dan bhakti kepada Tuhan. Dengan seringnya berkumpul dan beriteraksi antara umat yang satu dan umat yang lainnya, menjadikan hubungan kekuluargaan yang erat dan hangat dapat terjalin setiap saat. Moment yang telah telaksana secara rutin ini menjadi moment yang ditungu-tunggu untuk menjalin kedekantan sosoial yang harmonis dan damai.

Persembahyangan Purnama dan Tilem di Pura Jagadnatha Bangutopo menjadi waktu yang sangat penting bagi umat. Model pelaksanaan persembahyangan sepreti ini akan menjadi contoh dan pedoman bagi persembahyangan di tempat-tempat yang lain. Karena dengan menerapakan model seperti ini, umat Hindu menjadi semakun maju baik dalam hal 
Sraddha dan Bhakti, Pemahaman dan pengetahuan Agama serta pemaknaan-pemaknaan dalam ssetiap ritual adat Hindu. Sudah saatnya lembaga-lembaga Hindu baik itu Bimas Hindu dan Parisadha Hindu Dharma menganjurkan model pelaksanaan persembahyangan Purnama dan Tilem seperti yang sudah dilakukan di Pura Jagdnatha Banguntopo Bantul Yogyakarta.

\section{KEPUSTAKAA N}

1. Kadjeng, I Nyoman, dkk. 1994. Sarasamuscaya, Dengan Teks Bahasa Sansekerta dan Jawa Kuna. Surabaya : Paramita.

2. Mantra, I.B. 1998. Bhagawad Gita, Surabaya:Paramita

3. Oka Netra, A.A. Gde. 1994. Tuntunan Dasar Agama Hindu. Tim Penyusun

4. PHDI Pusat, 1993, Pedoman Pembinaan Umat Hindu Dharma Indonesia, Jakarta : Upada Sastra.

5. PHDI Kabupaten Karangasem, 2009, Filosofis Sembahyang, Arti dan Makna Sembahyanga. Amlapura

6. Prawiro, Ruslan, 1990. Ekonomi Sumberdaya. Bandung : Penerbit Alumni

7. Pudja, Gde, 1993. Bhagavadgita (Pancama Veda). Jakarta : Hanuman Sakti

8. Sugiyono. 2005. Memahami Penelitian Kualitatif. Bandung : Alfa Beta

9. Titib, I Made. 2003, Tri Sandya, Sembahyang dan Berdoa, Surabaya: Penerbit Paramita

10. Tambang Raras Niken, 2004, Purnama Tilem, Surabaya : PARAMITA

11. Widiana, I Ketut, 2009. Menjawab Pertanyaan Umat. Denpasar : Pustaka Bali Post

12. Widana, I Ketut, 2009. Esensi Pelaksanaan Persembahyangan Purnama Tilem Dalam Meningkatkan Kualitas Sraddha Bhakti Sisswa di SD Dangin Tukap Tahun Pelajaran 2008/2009. IHDN Denpasar

13. Yudha, Triguna, 2000, Teori Tentang Simbol. Denpasar : Widya Dharma

14. Referensi Internet:

15. http://inputbali.com/budaya-bali/makna-hari-purnama-dan-tilem-dalam-hindu

16. http://smbbali.blogspot.co.id/2012/11/hari-purnama-tilem.html

17. http://wayantarne.blogspot.co.id/2015/01/makna-filosofis-hari-raya-purnama-dan.html 